\title{
Respons Pertumbuhan dan Fisiologi Beberapa Varietas Tebu (Saccharum officinarum L.) Asal Kultur Jaringan yang Diberi Cekaman Genangan Air
}

\author{
Mochamad Arief Soleh', Santi Rosniawaty, dan Erza Febrilla Sofiani \\ Fakultas Pertanian Universitas Padjadjaran, Jalan Raya Bandung-Sumedang Km 21 \\ *Alamat korespondensi: m.arief@unpad.ac.id
}

\begin{abstract}
Growth and physiological responses of several sugarcane varieties (Saccharum officinarum L.) origin of tissue cultures under waterlogging
\end{abstract}

Sugarcane is the main comodity in sugar production. This production is affected by abiotic factor such as water. Uneven distribution of rainfall due to global warming has the potential to inundate in agricultural areas. This study aim was to evaluate growth and physiological responses among sugarcae seedling derived from tissue culture propagation. The experiment used randomize block design consisted of 8 treatments and 4 replications. The treatments consisted of 4 differences varieties namely PSJT 941, PS 862, PSJK 922 and Kidang Kencana with normal condition and flooding. The results showed significantly difference of growth and physiological responses among the varieties. In growth parameter, PSJT 941 was the best variety for plant heigh of $161.7 \mathrm{~cm}$, PS862 was the best for tillers number of 3.75, shoot and root weight of $38.68 \mathrm{~g}$ and $48.7 \mathrm{~g}$. In otherhand physiological parameter was best of PSJK 922 on stomata conductance of $261.6 \mathrm{mmol}$ $\mathrm{H}_{2} \mathrm{O} \cdot \mathrm{m}^{-2} \cdot \mathrm{s}^{-1}$, and Kidang Kencana was the best of chlorophyll fluorecence response ( $\mathrm{fv} / \mathrm{fm}$ ) of 0.723 .

Keywords: Abiotic Stress, Fv/Fm, Stomata, Sugarcane, Waterlogging

\begin{abstract}
ABSTRAK
Tanaman tebu merupakan komoditas utama penghasil gula. Produksi tebu dipengaruhi oleh faktor abiotik yaitu air. Sebaran curah hujan yang tidak merata akibat pemanasan global berpotensi terjadinya penggenangan di areal pertanian. Penelitian ini bertujuan untuk mengevaluasi respons sifat-sifat pertumbuhan dan fisiologis bibit tebu asal kultur jaringan yang diberikan cekaman genangan air. Percobaan menggunakan Rancangan Acak Kelompok (RAK) dengan 8 perlakuan, 4 ulangan dan setiap plot terdiri dari 3 tanaman. Perlakuan terdiri dari 4 jenis varietas yang berbeda yaitu PSJT 941, PS 862, PSJK 922 dan Kidang Kencana pada kondisi normal dan penggenangan. Hasil penelitian menunjukkan bahwa terdapat respons pertumbuhan dan fisiologi yang berbeda dari setiap varietas yang diuji. Varietas yang menunjukkan respons terbaik adalah PSJT 941 pada parameter tinggi tanaman yaitu $161,7 \mathrm{~cm}$; varietas PS 862 pada parameter jumlah anakan 3,75 buah, bobot kering tajuk yaitu 38,68 g dan akar 48,70 g; varietas PSJK 922 pada konduktansi stomata $\left(\mathrm{k}_{\mathrm{s}}\right)$ yaitu $261,6 \mathrm{mmol} \mathrm{H} \mathrm{H}_{2} \mathrm{O} \cdot \mathrm{m}^{-2} \cdot \mathrm{s}^{-1}$; dan varietas Kidang Kencana pada fv/fm yaitu 0,723.
\end{abstract}

Kata Kunci: Genangan air, Fv/Fm, Tebu, Stomata, Stres abiotik

\section{PENDAHULUAN}

Produksi tebu pada tiga tahun terakhir mengalami fluktuasi, seperti pada tahun 2015 mencapai 2,5 juta ton sedangkan pada tahun 2016 mengalami penurunan yaitu 2,2 juta ton, pada tahun 2017 mengalami penurunan kembali menjadi 1,12 juta ton, dan pada tahun 2018 sedikit mengalami peningkatan menjadi 2,17 juta ton untuk produksi tebu nasional (Dirjenbun, 2018). Usaha yang dapat dilakukan untuk memenuhi kebutuhan gula nasional salah satunya dengan peningkatan produksi tebu di lahan pertanian melalui sistem budidaya yang baik.

Peningkatan produksi tebu dapat dicapai apabila faktor-faktor pertumbuhan tebu mendukung dengan baik. Faktor yang berpengaruh terhadap pertumbuhan tanaman tebu diantaranya adalah 
faktor abiotik yaitu air, $\mathrm{CO}_{2}$, cahaya dan nutrisi, khususnya air yang menjadi faktor penting untuk pertumbuhan. Produksi gula yang tinggi memerlukan pasokan air yang tepat sesuai umur tanaman tebu. Air memiliki peranan penting sebagai pelarut berbagai senyawa molekul organik, transportasi fotosintat, menjaga turgiditas sel dalam pembesaran dan pertumbuhan sel (Salisbury \& Ross, 1995). Air yang berlebih dapat disebabkan oleh mencairnya es di kutub akibat dari peningkatan suhu bumi. Dalam kurun waktu 10 tahun terakhir, terjadi peningkatan suhu bumi yang diperlihatkan dengan kenaikan kadar $\mathrm{CO}_{2}$ yang signifikan di atmosfer sehingga terjadilah fenomena global warming yang saat ini tidak bisa dihindari. Intergovernmental Panel for Climate Change (IPCC) pada saat ini melaporkan konsentrasi $\mathrm{CO}_{2} \mathrm{di}$ atmosfer sudah melebihi $400 \mathrm{ppm}$ (IPCC, 2007). Perubahan iklim ini dapat memengaruhi sebaran curah hujan menjadi tidak merata (Soleh dkk., 2017). Curah hujan berlebih menyebabkan kondisi areal pertanian kelebihan air. Kondisi kelebihan air pada drainase lahan yang buruk dapat menyebabkan genangan sehingga tanaman mengalami cekaman genangan air. Genangan ini merupakan gangguan alam yang memengaruhi produksi tanaman di seluruh dunia (Serres \& Voesenek, 2008; Colmer \& Voesenek, 2009).

Usaha untuk mengurangi efek cekaman genangan air pada tanaman salah satunya dengan memperbaiki sifat bibit. Bibit merupakan salah satu faktor yang menentukan keberhasilan budidaya tebu dan terbentuknya kemampuan rendemen serta biomassa tanaman (Putri dkk., 2013). Pemakaian bibit yang murni dan bermutu dapat meningkatkan produksi sebesar 19\% dengan peningkatan pendapatan hampir dua kali dari tambahan biaya pengadaan bibit tersebut (Nahdodin, 1993). Bibit berkualitas ditandai dengan adaptasi yang baik pada lingkungan tertentu, dapat tumbuh dan berkembang dengan baik dan normal (Irwan \& Edi, 2012). Oleh karena itu penggunaan bibit unggul bermutu merupakan faktor produksi yang mutlak harus dipenuhi. Tanaman tebu dapat diperbanyak secara vegetatif yang dikenal sebagai bibit bagal dan bibit kultur jaringan. Bibit tebu yang berasal dari bagal sudah memasyarakat di lingkungan petani karena tidak memerlukan teknologi tinggi dan perawatan yang rumit, namun waktu penyediaan bibit yang dibutuhkan lebih lama dibandingkan dengan bibit yang berasal dari kultur jaringan (Budi, 2016). Teknik kultur jaringan merupakan metode alternatif yang dapat digunakan untuk memperbanyak tanaman tebu dengan menghasilkan bibit jumlah besar dalam waktu yang relatif singkat, pertumbuhan seragam, bebas patogen, dan produksi bibit yang tidak tergantung musim (Farid, 2003). Cara in vitro seperti pada metode kultur jaringan diharapkan dapat memberi solusi varietas yang tahan, toleransi ataupun peka terhadap genangan.

Kebutuhan air yang cukup selama masa pertumbuhan tanaman tebu dapat dipengaruhi oleh faktor biotik dan abiotik. Pada fase awal pertumbuhan hingga pemanjangan batang tebu kebutuhan air umumnya relatif tinggi dan menurun pada saat memasuki fase pemasakan. Fase pertumbuhan cepat atau perpanjangan merupakan fase paling kritis, dengan kebutuhan air mencapai $7,5-8,5 \mathrm{~mm} / \mathrm{hari}$ (P3GI, 2008). Pada kondisi air yang berlebih disebut cekaman genangan yang akan menimbulkan respons berbeda tergantung pada varietas tanaman yang digunakan dan tingkat cekaman (Pucciariello and Perata, 2013).

Kerusakan yang dialami oleh tanaman akibat adanya penggenangan akan memengaruhi pertumbuhan tanaman (Susilawati dkk., 2012). Zhao dan Li (2015) menyatakan bahwa pertanaman tebu yang terkena cekaman genangan air dapat menurun produksinya. Penampilan morfologi daun tanaman tebu yang mengalami genangan cenderung mengalami klorosis dan hambatan pertumbuhan bahkan kematian keseluruhan jaringan tanaman (Rachmawati \& Retnaningrum, 2013). Tebu dilaporkan dalam beberapa penelitian dapat hidup beberapa bulan selama penggenangan (Deren \& Raid, 1997). Munculnya stres lingkungan abiotik akan terjadi bersamaan dengan perubahan bentuk dan tampilan morfologi tanaman khususnya akar (Vartapetian \& Jackson, 1997; Jackson \& Colmer, 2005). Pada kondisi genangan akar tanaman akan cenderung memanjang lebih cepat menuju daerah kaya akan oksigen. Kondisi genangan dapat menurunkan pertukaran gas antara tanah dan udara yang mengakibatkan menurunnya ketersediaan oksigen bagi akar dan menghambat pasokan oksigen bagi akar dan mikroorganisme, sehingga pertumbuhan akar akan terlihat lebih dominan dibanding pada kondisi normal (Nishiuchi et al., 2012).

Perubahan morfologi yang terjadi pada tanaman merupakan bentuk penyesuaian beberapa varietas tebu terhadap cekaman air (Winkel et al., 2014). Beberapa akar mengalami kerusakan akibat cekaman air, sehingga jumlah akar akan meningkat dengan tujuan agar pengikatan unsur hara lebih maksimal sehingga dapat tetap disalurkan ke daun 
dan tanaman mampu melakukan fotosintesis walaupun tidak sebaik pada waktu tanaman tidak mengalami cekaman air (Miro \& Ismail, 2013). Perubahan morfologi yang lain adalah terdapat korelasi antara genangan dan tinggi tanaman (VanToai et al., 2007). Penggenangan yang lebih lama akan mengurangi tinggi tanaman, pengurangan berat daun, perkembangan akar adventif yang lebih besar dan pembesaran diameter pipa aerenkim pada tanaman tebu (Gilbert et al., 2007; Sullivan et al., 2001).

Konduktansi stomata merupakan salah satu parameter respons terhadap kondisi genangan. Konduktansi stomata merupakan kemampuan stomata untuk membuka dan menutup. Stomata berperan sebagai alat pertukaran gas $\mathrm{CO}_{2}$ dan $\mathrm{H}_{2} \mathrm{O}$ dari dalam ke luar tanaman dan sebaliknya. Menurut Davies dan Flore (1986), konduktansi stomata tanaman menurun bahkan terhenti pada kondisi tergenang bila metabolismenya terhambat. Hal ini dibuktikan pada penelitian Soleh dkk (2017) yang menunjukkan bahwa terjadi penurunan nilai konduktansi stomata pada tanaman tebu varietas Kidang Kencana sebesar 62\% saat kondisi tergenang air. Stomata akan menutup pada kondisi genangan yang menyebabkan proses transpirasi dan fotosintesis terhambat. Tingkat toleransi varietas tanaman terhadap genangan bergantung pada lamanya penutupan. Kondisi tergenang juga dapat meningkatkan kerapatan stomata (Lestari, 2006).

Respons varietas yang peka terhadap cekaman genangan yaitu dengan menghentikan pertumbuhan hingga kematian sedangkan varietas toleran akan membentuk jaringan aerenkim dan memacu pertumbuhan untuk menghindari stres (Mickelbart et al., 2015). Hal ini dibuktikan pada penelitian Avivi dkk. (2018) yang menunjukkan bahwa pada tanaman tebu varietas VMC 76-16 terdapat jaringan aerenkim yang sempurna dengan rongganya yang lebih lebar dan lebih merata. Menurut Pezeshki dan DeLaune (2012), terbentuknya jaringan aerenkim merupakan syarat utama tanaman untuk mempertahankan aktivitas akarnya dalam menyerap unsur hara dan air serta untuk mempertahankan metabolismenya selama dalam keadaan tercekam genangan.

Kemampuan tanaman dapat mentolerir tekanan lingkungan juga dapat diketahui melalui respons flouresensi (Maxwell \& Johnson, 2000). Metode fluoresensi mengukur nilai kuantum efisiensi (Fv/Fm) yang memungkinkan prediksi tingkat keparahan akibat cekaman dengan resolusi dan akurasi yang tinggi (Baker, 2008). Olsen (2016) menyatakan bahwa terjadi penyusutan nilai $\mathrm{fv} / \mathrm{fm}$ yang signifikan pada tanaman yang terkena cekaman dibandingkan dengan kontrol. Hal ini dibuktikan pada penelitian Soleh et al. (2018) bahwa nilai fv/fm varietas PS 862 menyusut dari 0,8 menjadi 0,6 setelah 7 hari penggenangan. Saat ini ada beberapa varietas tebu yang mampu diusahakan di lahan basah seperti PSJT 941, PS 862, PSJK 922 dan Kidang Kencana. Pada kondisi lahan jenuh air, varietas PSJT 941 memiliki keunggulan dalam pertumbuhan, sedangkan PSJK 922 unggul dalam proses fisiologi (Soleh et al., 2018). Varietas Kidang Kencana merupakan varietas yang sensitif terhadap kelebihan air (Soleh et al., 2018). Penelitian ini dilakukan untuk mengevaluasi sifat-sifat toleran pada bibit tebu asal kultur jaringan yang diberikan cekaman genangan air yaitu dengan pertumbuhan dan fisiologi yang dapat menggambarkan tingkat toleransi setiap varietas, sehingga dapat menghasilkan informasi mengenai varietas tebu yang memiliki tingkat toleransi terbaik.

\section{BAHAN DAN METODE}

Bahan tanaman yang digunakan adalah empat varietas tebu yakni PSJT 941, PS862, PSJK 922, dan Kidang Kencana (KK). Tanaman ditanam dalam polibeg berukuran volume $5 \mathrm{~kg}$, dengan media tanam adalah tanah Inceptisol. Tiap tanaman diberikan pupuk dasar NPK $10 \mathrm{~g}$ per polibeg. Tanaman ditempatkan di rumah plastik di lahan percobaan Fakultas Pertanian, Universitas Padjadjaran dari bulan Oktober 2018-Januari 2019. Perlakukan genangan air dilakukan dengan memindahkan polibeg pada ember berukuran besar yang telah diisi air dengan ketinggian air $30 \mathrm{~cm}$ sehingga dipastikan polibeg seluruhnya tergenang air. Penelitian ini dilaksanakan menggunakan Rancangan Acak Kelompok (RAK) sederhana yang terdiri dari 8 perlakuan yang diulang sebanyak 4 kali dimana setiap satuan percobaan terdiri dari 3 tanaman, sehingga total tanaman tebu yang digunakan adalah 96 tanaman. Adapun perlakuan yang digunakan dalam percobaan adalah sebagai berikut:
$\mathrm{V}_{1}$ : PSJT 941
$\mathrm{V}_{2}$ : PS 862
$\mathrm{V}_{3}$ : PSJK 922
$\mathrm{V}_{4}$ : Kidang Kencana
$V_{5}$ : PSJT $941+$ Penggenangan
$\mathrm{V}_{6}$ : PS $862+$ Penggenangan
$V_{7}$ : PSJK 922 + Penggenangan
$\mathrm{V}_{8}$ : Kidang Kencana + Penggenangan 
Pengamatan yang dilakukan adalah pengamatan terhadap karakter morfologi tanaman meliputi: tinggi, jumlah anakan, dan bobot kering tajuk dan akar tanaman. Pengamatan terhadap karakter fisiologis meliputi: konduktansi stomata menggunakan alat porometer (Decagon device inc., US) dan klorofill fluorescence ( $\mathrm{fv} / \mathrm{fm}$ ) mengunakan alat Handypea (Hansatech Instrument). Perlakuan penggenangan dilakukan pada tanaman berumur 60 hari stelah tanam (HST), dengan durasi penggenangan 30 hari.

\section{HASIL DAN PEMBAHASAN}

\section{Tinggi Tanaman}

Data tinggi tanaman menunjukkan terdapat respons yang berbeda diantara perlakuan V1-V8. Empat varietas tebu menunjukkan perbedaan respons pada perlakuan tanpa dan dengan genangan. Pada umur tanam 8 MST atau sebelum perlakuan genangan, pertambahan tinggi tanaman berkisar dari $53,3 \mathrm{~cm}$ untuk perlakuan V7 sampai 104,7 cm untuk perlakuan V5. Sedangkan pada 10 MST atau 2 minggu setelah perlakuan genangan pertambahan tinggi tanaman mulai dari $70.1 \mathrm{~cm}$ untuk perlakuan V7 sampai 130,7 cm untuk perlakuan V5. Pada 12 MST atau 4 minggu setelah penggenangan pertambahan tinggi tanaman mulai dari $85,1 \mathrm{~cm}$ untuk perlakuan V7 sampai $161,7 \mathrm{~cm}$ untuk perlakuan V5 (Table 1).

Dari hasil pengamatan tinggi tanaman ini, perlakuan V5 memperlihatkan pertambahan tinggi tanaman tertinggi dibanding perlakuan lainya seperti perlakuan V6 dan V7. Dari pengamatan ini tampak adanya diversitas respons pertambahan tinggi diantara empat varietas tebu yang diamati. Varietas PSJK941 memiliki respons pertambahan tinggi terbaik dalam kondisi genangan dan non genangan menandakan varietas ini memiliki keunggulan sifat morfologi khususnya dalam keadaan cekaman genangan air. Tanaman yang tidak mengalami cekaman genangan air menghasilkan tinggi tanaman yang paling tinggi dibandingkan dengan tanaman yang tercekam (Pervez et al., 2009). Hal ini didukung oleh Kawano et al. (2009) yang menyebutkan bahwa adanya penggenangan dapat memacu elongasi batang untuk membantu mencukupi kebutuhan oksigen dan karbondioksida untuk mendukung respirasi aerob dan fotosintesis.

\section{Jumlah Anakan}

Semua perlakuan genangan dan non genangan V1 - V8 memperlihatkan respons jumlah anakan yang tidak signifikan berbeda pad umur 8 MST - 12 MST (Tabel 2). Trend respons jumlah anakan berkisar pada 2 anakan untuk perlakuan V8 sampai 5 anakan untuk perlakuan V1 pada akhir masa akhir pengenangan yaitu 12 MST. Hal ini menandakan perlakuan genangan cenderung menurunkan jumlah anakan tanaman tebu. Dalam kondisi cekaman genangan, pertumbuhan tanaman akan cenderung diarahkan ke root dan atau shoot untuk mengatasi kekurangan oksigen, sehingga pertumbuhan anakan kemunginan akan tertekan (Bakrie dkk., 2010). Hal ini dapat dilihat pada perlakuan dengan genangan (V5-V8) jumlah ratarata anakanakn cenderung lebih rendah dari perlakuan tanpa genangan (V1-V4) walaupun secara statistik tidak berbeda nyata.

\section{Bobot Kering Tajuk dan Akar}

Bobot kering tajuk berkisar antara 10,4 g untuk perlakuan V7 sampai 40,3 untuk perlakuan V2, sedangkan bobot kering akar berkisar antara 4,4 g pada perlakuan V8 sampai 48,7 pada perlakuan V6 (Tabel 3). Secara umum, perlakuan genangan memperlihatkan bobot kering tajuk lebih kecil dibandingkan dengan bobot kering akar. Hal tersebut merupakan hal umum bahawa tanaman yang menghadapi cekaman genangan akan cenderung memperbanyak akar serabut untuk mengatasi kekurangan oksigen. Akibatnya pertumbuhan akan cenderung diarahkan pada organ yang mengalami cekamana genangan yaitu akar. Hasil penelitian Budi (2000) menyatakan bahwa bobot kering akar per tanaman meningkat pada penggenangan air. Hal ini disebabkan oleh pertumbuhan akar adventif pada tanaman yang tergenang akan terbentuk pada bagian atas akar mendekati permukaan tanah dimana oksigen tersedia lebih tinggi. Pada parameter bobot kering tajuk dan akar, varietas PS862 memperlihatkan respons terbaik dibanding dengan perlakuan lainya seperti KK dan PSJK922. Hal ini memungkinkan varietas PS862 memiliki keungulan morfologi dalam keadaan cekaman genangan seperti halnya varietas PSJT 941 pada parameter tinggi tanaman, selain itu pada Tabel 3 perbedaan bobot kering tajuk dan akar antara varietas PSJK 941 dan PS862 tidak berbeda nyata secara statistic. 
Tabel 1. Tinggi tanaman empat varietas tebu pada keadaan tanpa penggenangan dan penggenangan 8,10 , dan 12 MST

\begin{tabular}{lccc}
\hline \multirow{2}{*}{ Perlakuan } & \multicolumn{3}{c}{ Tinggi tanaman $(\mathrm{cm})$} \\
\cline { 2 - 4 } & $8 * \mathrm{MST}$ & $10 \mathrm{MST}$ & $12 \mathrm{MST}$ \\
\hline V1 (PSJT 941) & $85,60 \mathrm{ab}$ & $107,50 \mathrm{ab}$ & $155,50 \mathrm{bc}$ \\
V2 (PS 862) & $82,00 \mathrm{ab}$ & $97,20 \mathrm{ab}$ & $127,00 \mathrm{abc}$ \\
V3 (PSJK 922) & $71,80 \mathrm{ab}$ & $92,90 \mathrm{ab}$ & $126,20 \mathrm{abc}$ \\
V4 (KK) & $60,60 \mathrm{ab}$ & $81,00 \mathrm{ab}$ & $118,00 \mathrm{abc}$ \\
V5 (PSJT 941 + Penggenangan) & $104,70 \mathrm{~b}$ & $130,70 \mathrm{~b}$ & $161,70 \mathrm{c}$ \\
V6 (PS 862 + Penggenangan) & $58,80 \mathrm{a}$ & $80,70 \mathrm{ab}$ & $105,40 \mathrm{ab}$ \\
V7 (PSJK 922 + Penggenangan) & $53,30 \mathrm{a}$ & $70,10 \mathrm{a}$ & $85,10 \mathrm{a}$ \\
V8 (KK + Penggenangan) & $65,30 \mathrm{ab}$ & $82,80 \mathrm{ab}$ & $99,80 \mathrm{a}$ \\
\hline
\end{tabular}

Keterangan: Nilai rata-rata yang diikuti huruf yang sama pada kolom yang sama menunjukkan tidak berbeda nyata berdasarkan uji Tukey pada taraf 5\%. (*): Sebelum penggenangan.

Tabel 2. Jumlah anakan empat varietas tebu pada keadaan tanpa penggenangan dan penggenangan

\begin{tabular}{lccc}
\hline \multirow{2}{*}{ Perlakuan } & \multicolumn{3}{c}{ Jumlah anakan (buah) } \\
\cline { 2 - 4 } & $\mathbf{8}^{*}$ MST & $10 \mathrm{MST}$ & 12 MST \\
\hline V1 (PSJT 941) & 1,00 & 3,00 & 4,75 \\
V2 (PS 862) & 2,25 & 3,00 & 4,25 \\
V3 (PSJK 922) & 1,25 & 3,00 & 3,25 \\
V4 (KK) & 0,50 & 1,50 & 2,75 \\
V5 (PSJT 941 + Penggenangan) & 2,50 & 2,75 & 2,75 \\
V6 (PS 862 + Penggenangan) & 1,75 & 3,25 & 3,75 \\
V7 (PSJK 922 + Penggenangan) & 2,00 & 2,75 & 2,75 \\
V8 (KK + Penggenangan) & 1,50 & 2,00 & 2,00 \\
\hline
\end{tabular}

Keterangan: Nilai rata-rata yang diikuti huruf yang sama pada kolom yang sama menunjukkan tidak berbeda nyata berdasarkan uji Tukey pada taraf 5\%. (*): Sebelum penggenangan.

Tabel 3. Bobot kering tajuk dan akar keempat varietas tebu pada keadaan tanpa penggenangan dan penggenangan umur $12 \mathrm{MST}$

\begin{tabular}{lcc}
\hline \multirow{2}{*}{ Perlakuan } & \multicolumn{2}{c}{ Bobot kering tajuk dan akar } \\
\cline { 2 - 3 } & Tajuk $(\mathrm{g})$ & Akar $(\mathrm{g})$ \\
\hline V1 (PSJT 941) & $25,35 \mathrm{ab}$ & $8,38 \mathrm{ab}$ \\
V2 (PS 862) & $40,33 \mathrm{~b}$ & $26,94 \mathrm{ab}$ \\
V3 (PSJK 922) & $25,41 \mathrm{ab}$ & $12,87 \mathrm{ab}$ \\
V4 (KK) & $30,76 \mathrm{ab}$ & $6,51 \mathrm{a}$ \\
V5 (PSJT 941 + Penggenangan) & $19,06 \mathrm{ab}$ & $34,76 \mathrm{ab}$ \\
V6 (PS 862 + Penggenangan) & $38,68 \mathrm{~b}$ & $48,70 \mathrm{~b}$ \\
V7 (PSJK 922 + Penggenangan) & $10,43 \mathrm{a}$ & $20,20 \mathrm{ab}$ \\
V8 (KK + Penggenangan) & $12,98 \mathrm{a}$ & $4,44 \mathrm{a}$ \\
\hline
\end{tabular}

Keterangan: Nilai rata-rata yang diikuti huruf yang sama pada kolom yang sama menunjukkan tidak berbeda nyata berdasarkan uji Tukey pada taraf 5\%.

Konduktansi Stomata (ks) dan Klorofil Fluorescence $(\mathrm{fv} / \mathrm{fm})$

Terdapat perbedaan respons konduktansi stomata dan klorofil fluorescence dari ke empat varietas tebu yang diamati. Perlakuan penggenangan cenderung menyebabkan turunnya nilai konduktansi stomata (Gambar 1A) pada 30 hari pengenangan. Hal ini sejalan dengan penurunnya nilai fv/fm (Gambar 1B). Penghentian penggenangan menyebabkan nilai ks naik kembali. 

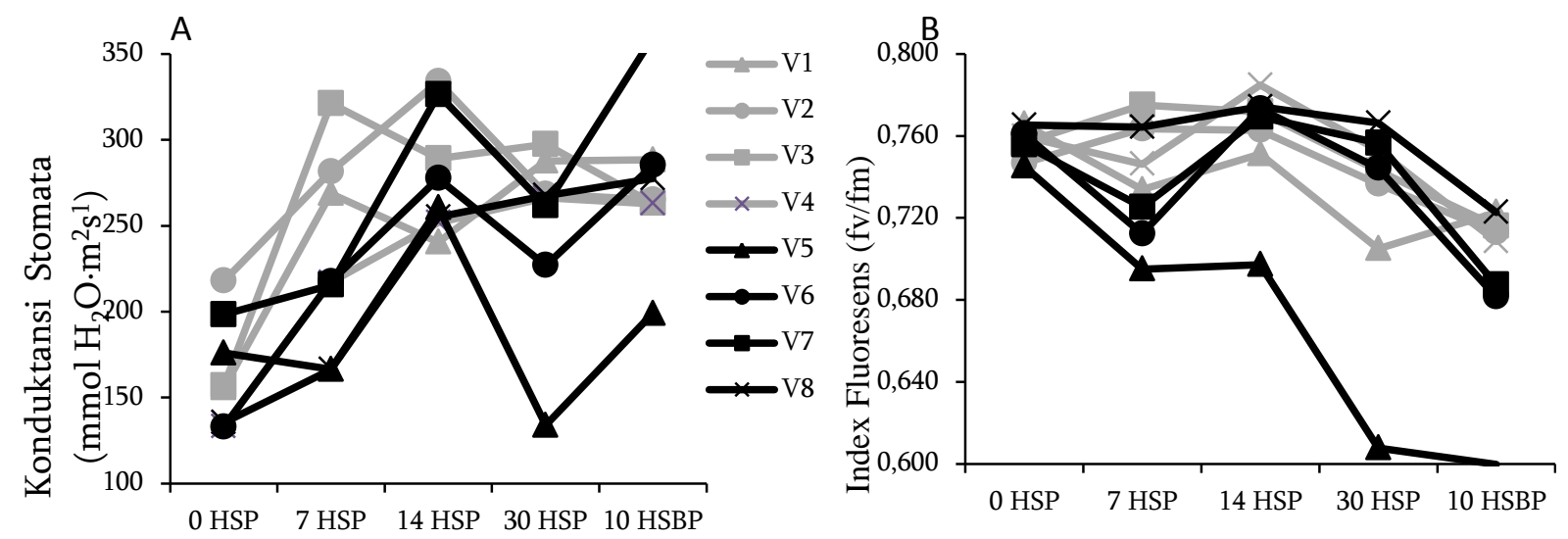

Gambar 1. Nilai konduktansi stomata (A) dan fv/fm (B) empat varietas tebu pada penggenangan 0 HSP, 7 HSP, 14 HSP, 30 HSP dan 10 HSBP (9 MST-13 MST).

Secara umum perlakuan genangan air menyebakan nilai konduktansi stomata diantara varietas tebu lebih rendah dari varietas tanpa perlakuan genangan. Hal ini seperti terlihat pada 7 Hari Setelah Perlakuan (HSP), nilai konduktansi stomata V5 sampai V8 menunjukkan nilai lebih rendah dibandingkan perlakuan tanpa genangan yaitu V1 sampai V4 (Gambar 1A). Pada 14 HSP, nilai konduktansi stomata perlakuan V5 sampai V8 mengalami peningkatan sehingga mendekati atau melebihi nilai konduktansi stomata perlakuan tanpa penggenangan yaitu V1 sampai V4. Pada perlakuan pengenangan ringan yaitu dibawah 14 hari semua varietas tebu memperlihatkan respons positif meningkat menandakan semua varietas tanaman memiliki ketahanan terhadap cekaman ringan tersebut. Tanaman akan menunjukkan penurunan nilai koduktansi stomata sesaat setelah mengalami cekaman abiotik, namun untuk varietas yang tahan cekaman nilai koduktansi stomata tersebut akan mengakami peningkatan kembali pada beberapa hari atau minggu ketika penggenangan berlanjut. Hal ini seperti yang terjadi pada tanaman Fraxinus pennsylvanica Marsh (Sena Gomes \& Kozlowski, 1980). Sementara itu, pada tanaman yang rentan terhadap cekaman abiotik nilai stomata akan terus menurun dalam waktu yang lebih lama (Kozlowski, 1984).

Lain halnya pada perlakuan cekaman lanjutan yakni sampai 30 hari, pada Gambar 1, tampak varietas PSJT 941 mengalami penurunan nilai konduktansi stomata samapai di bawah 150 $\mathrm{mmol} \mathrm{H}_{2} \mathrm{O} \cdot \mathrm{m}^{2} \mathrm{~s}^{1}$. Varietas PSJT ini diduga memiliki karakter flood escape dengan mempercepat pertumbuhan morofologi seperti pada pertambahan tinggi, berat kering tajuk dan akar. Berdasarkan karakter fisiologis, varietas lainnya seperti PS862 dan PSJK922 cenderung memiliki karakter tolerant karena nilai konduktansi stomata pada perlakuan penggenangan lanjutan tetap tinggi yakni lebih dari $200 \mathrm{mmol} \mathrm{H}_{2} \mathrm{O} \cdot \mathrm{m}^{2} \mathrm{~s}^{1}$. Tebu merupakan tanaman $\mathrm{C} 4$ yakni tanaman yang efisien dalam melakukan proses metabolisme fotosintensis dengan menjaga konsentrasi $\mathrm{CO}_{2}$ dalam daun tetap tinggi walaupun nilai konduktansi stomata rendah. Hal ini terlihat pada pengukuran respons $\mathrm{fv} / \mathrm{fm}$ semua varietas pada perlakuan genangan memperlihatkan nilai fv/fm di atas 0,7 pada pengenangan 14 dan 30 hari kecuali varietas PSJT941 (Gambar 1B), menandakan proses metabolisme fotosintesis berjalan dengan baik. Bolhàr-Nordenkampf et al. (1989) melaporkan bahwa ketika tanaman menjaga kompleks fotosintesisnya utuh, rasio $\mathrm{fv} / \mathrm{fm}$ harus bervariasi antara 0,750 dan 0,850 . Tanaman yang mengalami cekaman akan memengaruhi tingkat metabolismenya dengan menurunnya nilai konduktansi stomata (Soleh et al., 2018). Nilai fv/fm di atas 0,7 dengan nilai konduktasi stomata relatif rendah menandakan tanaman tebu merupakan tanaman yang efisien. Sementara itu, penurunan nilai stomata pada tahap tertentu seperti pada tingkat cekaman yang parah, menandakan gejala stres sedang terjadi. Tanaman yang mengalami cekaman akan memengaruhi tingkat metabolismenya dengan menurunnya nilai konduktansi stomata (Soleh et al., 2018).

\section{SIMPULAN}

Terdapat respons yang berbeda terhadap cekaman genangan air yaitu dengan mempercepat pertumbuhan dan mempertahankan respons 
fisiologis daun. Varietas yang memberikan respons terbaik terhadap cekaman genangan air adalah varietas PSJT 941 pada parameter tinggi tanaman yaitu 161,7 cm; varietas PS 862 pada parameter jumlah anakan 3,75 buah, bobot kering tajuk yaitu 38,68 g dan akar 48,70 g; varietas PSJK 922 pada konduktansi stomata $\left(\mathrm{k}_{\mathrm{s}}\right)$ yaitu 261,6 $\mathrm{mmol} \mathrm{H}_{2} \mathrm{O} \cdot \mathrm{m}^{-}$ ${ }^{2} \cdot \mathrm{s}^{-1}$; dan varietas Kidang Kencana pada fv/fm yaitu 0,723 .

\section{UCAPAN TERIMA KASIH}

Ucapan terima kasih kepada DRPMUniversitas Padjadjaran yang telah mendanai penelitian ini melalui skema RFU-HIU tahun 20172018.

\section{DAFTAR PUSTAKA}

Avivi, S, A Syamsunihar, S Soeparjono, dan M Chozin. 2018. Toleransi berbagai varietas tebu terhadap penggenangan pada fase bibit berdasarkan karakter morfologi dan anatomi. Jurnal Agronomi Indonesia. 46 (1): 103-110.

Baker, NR. 2008. Chlorophyll Fluorescence: A Probe of Photosynthesis in Vivo. Annual Review of Plant Biology (59): 89-113.

Bakrie, MM, I Anas, Sugiyanta, dan K Indris. 2010. Aplikasi pupuk anorganik dan organik hayati pada budidaya padi SRI (System of Rice Intensification). Jurnal Tanah Lingkungan. (12): 25-32.

Bolhàr-Nordenkampf, HR, SP Long, NR Baker, G Öquist, U Schreider, and EG Lechner. 1989. Chlorophyll fluorescence as probe of the photosynthetic competence of leaves in the field: A review of current instrument. Functional Ecol. 3:497-514.

Budi, S. 2016. Teknologi Pembuatan Bibit Tebu (Saccharum officinarum L.) Unggul Bersertifikat. UMM Press. Malang Hlm 2526.

Colmer, TD, and LACJ Voesenek. 2009. Flooding tolerance: suites plant traits in variable environments. Functional Plant Biology. (36): 665-681.

Davies, FS, and JA Flore. 1986. Flooding, gas exchange and hydraulic conductivity of highbush blueberry. Physiology Plantarum (67): 545-551.

Deren, CW, and RN Raid. 1997. Yield components of sugarcane subjected to flood at planting. J
Am Soc Sugar Cane Technology. (17): 2837.

Dirjenbun. 2018. Direktorat Jendaral Perkebunan Tahun 2018. Direktorat Jendral Perkebunan. Jakarta.

Farid, M. 2003. Perbanyakan tebu (Saccharum officinarum L.) secara in vitro pada berbagai konsentrasi IBA dan BAP. Jurnal Sains \& Teknologi. 3(30): 103-109.

Gilbert, RA, CR Rainbolt, DR Morris, and AC Bennett. 2007. Morphological responses of sugarcane to long-term flooding. Agronomy Journal. (99): 16-28.

IPCC. 2007. Climate change 2007: The physical science basis. Summary for policy makers. Available online at http://www.ipcc.ch. Accessed January 2019.

Irwan, A dan P Edi. 2012. Pembuatan Persemaian dan Teknik Pembibitan. Operation Wallacea Trust. Bogor.

Jackson, MB, and TD Colmer. 2005. Response and Adaptation by Plants to Flooding Stress. Annals of Botany. 96: 501-505.

Kawano, N, O Ito, and J Sakagami. 2009. Morphological and physiological responses of rice seedlings to complete submergence (flash flooding). Annals of Botany. 103: 161169.

Kozlowski, TT. 1984. Responses of woody plants to flooding. Pp.129-163 in Flooding and Plant Growth (TT Kozlowski, Ed.). Academic Press. London.

Lestari, EG. 2006. Hubungan antara kerapatan stomata dengan ketahanan kekeringan pada somaklon padi Gajahmungkur, Towuti dan IR 64. Biodiversitas. 7(1): 44-48.

Maxwell, K, and GN Johnson. 2000. Chlorophyll fluorescence-A practical guide. Journal of Experimental Botany. 51: 659-668.

Mickelbart, MV, PM Hasegawa, and J Bailey-Serres. 2015. Genetic mechanisms of abiotic stress tolerance that translate to crop yield stability. Nature Reviews Genetics. 16: 237251.

Miro, B, and AM Ismail. 2013. Tolerance of anaerobic conditions caused by flooding during germination and early growth in rice (Oryza sativa L.). Frontiers Plant Science. (4): 269.

Nahdodin. 1993. Penyediaan Bibit Tebu Berkualitas, Permasalahan, dan Penanggulangannya. Gula Indonesia. XVIII (3): 39-41. 
Nishiuchi, S, T Yamauchi, H Takahashi, L Kotula, and M Nakazono. 2012. Mechanisms for coping with submergence and waterlogging in rice. Rice. 5: 2.

Olsen, DJ. 2016. The Fast fluorescence kinetics: a sensitive tool for early detection of water stress in sugarcane. Sugar Research Australia, Indooroopilly. Proc Aust Soc Sugar Cane Technol.Vol. 38. 2016.

Pervez, MA, CM Ayub, HA Khan, MA Shahid, and I Ashraf. 2009. Effect of drought stress on growth, yield and seed quality of tomato (Lycopersicon esculuntum L). Pak. J Agriculture Science. 46(3): 174-178.

Pezeshki, SR, and RD DeLaune. 2012. Soil oxidation reduction in wetlands and its impact on plant functioning. Biology (Basel). 1: 196221.

Pucciariello, C, and P Perata. 2013. Quiescence in rice submergence tolerance: An evolutionary hypothesis. Trends Plant Science. 18: 377-381.

Pusat Penelitian Perkebunan Gula Indonesia (P3GI). 2008. Konsep Peningkatan Rendemen untuk Mendukung Program Akselerasi Industri Gula Nasional.

Putri, AD, Sudiarso dan T Islami. 2013. Pengaruh komposisi media tanam pada teknik bud chip tiga varietas tebu (Saccharum officinarum L.). Jurnal Produksi Tanaman. 1(1): 16-23.

Rachmawati, D, dan E Retnaningrum. 2013. Pengaruh tinggi dan lama penggenangan terhadap pertumbuhan padi kultivar Sintanur dan dinamika populasi rhizobakteri pemfiksasi nitrogen non simbiosis. Bionatura-Jurnal Ilmu-ilmu Hayati dan Fisik. 15(2): 117-125.

Salisbury, FB, dan CW Ross. 1995. Fisiologi Tumbuhan Jilid 1. ITB. Bandung.

Sena-Gomes, AR, and TT Kozlowski. 1980. Growth responses and adaptations of Fraxinus pennsylvanica seedlings to flooding. Plant Physiology. 66: 267-271.

Serres, BJ, and LACJ Voesenek. 2008. Flooding stress: acclimations and genetic diversity.
Annual Review of Plant Biology. 59: 313339.

Singh, K. 1990. Sugarcane cultivated in waterlogging areas. Indian Sugar. 10: 537.

Soleh, M., M Ariyanti, IR Dewi, dan M Kadapi. 2018. Chlorophyll fluorescence and stomatal conductance of ten sugarcane varieties under waterlogging and fluctuation light intensity. Emirates Journal of Food and Agriculture. 30(11): 935-940.

Soleh, MA, R Manggala, Y Maxiselly, M Ariyanti, dan LRD Anjarsari. 2017. Respons konduktansi stomata beberapa genotipe tebu sebagai parameter toleransi terhadap stress abiotik. Jurnal Kultivasi. 16(3): 490493.

Sullivan, M, TT VanToai, N Fausey, J Beuerlein, R Parkinson, and A Soboyejo. 2001. Evaluating on-farm flooding impacts on soybean. Crop Science. (41): 93-100.

Susilawati, RA Suwignyo, Munandar, dan M Hasmeda. 2012. Karakter agronomi dan fisiologi varietas tanaman cabai merah pada kondisi cekaman genangan. Jurnal Agronomi Indonesia. 40 (3): 196-203.

VanToai, TT, TTC Hoa, NTN Hue, H Nguyen, JG Shannon, and B Bishop. 2007. Diversity in tolerance of soybean (Glicyne max L. Merr.) germplasm to soil waterlogging. Paper presented at International Annual Meetings, New Orleans, Louisiana,4-8 November 2007.

Vartapetian, BB, and M Jackson. 1997. Plant adaptations to anaerobic stress. Annals of Botany. 79: 3-20.

Winkel, A, O Pedersen, E Ella, AM Ismail, and TD Colmer. 2014. Gas film retention and underwater photosynthesis during field submergence of four contrasting rice genotypes. Journal of Experimental Botany. 65(12): 3225-3233.

Zhao, D, and YR Li. 2015. Climate change and sugarcane production: Potential impact and mitigation strategies. Internat. Journal of Agronomy. 2: 1-10. 